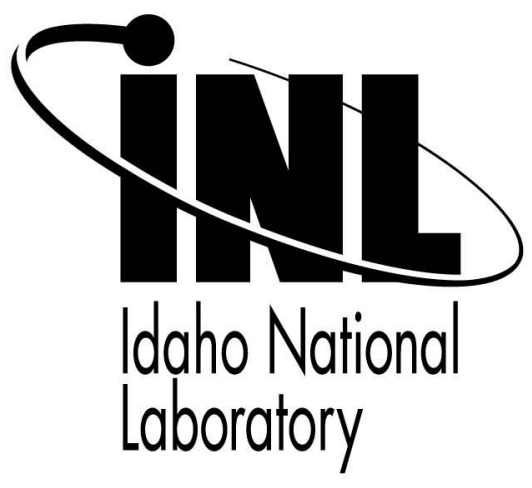

$11^{\text {th }}$ International Conference on Environmental Remediation and Radioactive Waste Management (ICEM 2007)

Jack Law

Dean Peterman

Cathy Riddle

David Meikrantz

Terry Todd

\title{
September 2007
}

This is a preprint of a paper intended for publication in a journal or proceedings. Since changes may be made before publication, this preprint should not be cited or reproduced without permission of the author. This document was prepared as an account of work sponsored by an agency of the United States Government. Neither the United States Government nor any agency thereof, or any of their employees, makes any warranty, expressed or implied, or assumes any legal liability or responsibility for any third party's use, or the results of such use, of any information, apparatus, product or process disclosed in this report, or represents that its use by such third party would not infringe privately owned rights. The views expressed in this paper are not necessarily those of the United States Government or the sponsoring agency. 


\section{ADVANCES IN DEVELOPMENT OF THE FISSION PRODUCT EXTRACTION PROCESS FOR THE SEPARATION OF CESIUM AND STRONTIUM FROM SPENT NUCLEAR FUEL}

\author{
Jack Law/ldaho National Laboratory
}

Cathy Riddle/INL
David Meikrantz/INL

\author{
Dean Peterman/INL
}

Terry Todd//NL

\section{ABSTRACT}

The Fission Product Extraction (FPEX) Process is being developed as part of the United States Department of Energy Advanced Fuel Cycle Initiative for the simultaneous separation of cesium (Cs) and strontium (Sr) from spent light water reactor (LWR) fuel. Separation of the Cs and Sr will reduce the shortterm heat load in a geological repository, and when combined with the separation of americium (Am) and curium (Cm), could increase the capacity of the geological repository by a factor of approximately 100 . The FPEX process is based on two highly specific extractants: 4,4',(5')-Di-(t-butyldicyclo-hexano)-18crown-6 (DtBuCH18C6) and Calix[4]arene-bis-(tertoctylbenzo-crown-6) (BOBCalixC6). The DtBuCH18C6 extractant is selective for strontium and the BOBCalixC6 extractant is selective for cesium. Results of flowsheet testing of the FPEX process with a simulated feed solution in 3.3-cm centrifugal contactors are detailed. Removal efficiencies, distribution coefficient data, coextraction of metals, and process hydrodynamic performance are discussed along with recommendations for future flowsheet testing with actual spent nuclear fuel.

\section{INTRODUCTION}

As part of the Advanced Fuel Cycle Initiative (AFCI), the reduction in volume and heat generation of spent nuclear fuel requiring geologic disposal is currently being addressed [1]. The goal is to optimize utilization of the nation's first repository and potentially reduce or eliminate the need for additional repositories. This goal can be achieved through separating long-lived, highly toxic elements; reducing highlevel waste volumes and the toxicity of spent nuclear fuel; and reducing the heat generation of spent nuclear fuel. The Idaho National Laboratory (INL) is working closely with a team of national laboratories and other organizations to support development of these separations processes.

Key to the reduction of short-term heat load in a geological repository is the separation of ${ }^{137} \mathrm{Cs}$ and ${ }^{90} \mathrm{Sr}$. Removing these highly radioactive fission products reduces the short-term ( $\sim 100 \mathrm{yr})$ heat-generation source of the spent nuclear fuel. Once separated, the $\mathrm{Cs}$ and $\mathrm{Sr}$ would be placed in storage until the activity has decayed to low-level waste (LLW) levels, at which time it could potentially be disposed of as a non-transuranic (TRU) LLW.

To support development of this separations process, technologies for simultaneouly separating $\mathrm{Cs}$ and $\mathrm{Sr}$ from dissolved spent nuclear fuel are being developed. In previous work, $\mathrm{Cs}$ and $\mathrm{Sr}$ have been removed from acidic nuclear waste solutions and related alkaline wastes using separate solventextraction processes designed specifically for these elements. In general, crown ethers have been selected to remove strontium, [2 - 4], and calixarenes [5 - 10] have been selected for separating cesium. A novel process is being developed at INL that combines these two types of extractants to constitute a solvent that will extract both cesium and strontium from acidic media, simultaneously. This technology, the Fission Product Extraction (FPEX) Process, utilizes 4,4',(5')-di-(tbutyldicyclohexano)-18-crown-6 (DtBuCH18C6) for the extraction of $\mathrm{Sr}$, calix[4]arene-bis-(tert-octylbenzo-crown-6) (BOBCalixC6) for the extraction of Cs, 1-(2,2,3,3tetrafluoropropoxy)-3-(4-sec-butylphenoxy)-2-propanol (Cs$7 \mathrm{SB}$ ) as a modifier, TOA (trioctylamine) and an Isopar $^{(B)} \mathrm{L}$ diluent. Initial development of the FPEX process at INL began 
in FY-04 [11]. Results from this initial testing were promising. Further testing was performed in FY-05 and FY-06.

Process goals for separating Cs and $\mathrm{Sr}$ from the spent LWR fuel require $\geq 99.9 \%$ removal. Additionally, the TRU content of the $\mathrm{Cs} / \mathrm{Sr}$ product must be less than $100 \mathrm{nCi} / \mathrm{g}$ so that this waste stream will be classified as a non-TRU LLW once the ${ }^{137} \mathrm{Cs}$ and ${ }^{90} \mathrm{Sr}$ decay. This requires a decontamination factor of approximately $1 \mathrm{E}+05$ to $1 \mathrm{E}+06$, depending on the fuel composition and preceding separation processes, for the TRU from the $\mathrm{Cs} / \mathrm{Sr}$ product. Laboratory testing indicates that the FPEX process can effectively separate $\mathrm{Cs}$ and $\mathrm{Sr}$ from acidic solutions containing large quantities of actinides and lanthanides, such as spent LWR fuel [11]. It should be noted that there are issues relative to the stability of the BOBCalixC6. Due to the alkyl substituent on the benzyl moiety of the BOBCalixC6, the benzyl ring is activated towards nitration. While nitration of the BOBCalixC6 does not severely impact the measured $\mathrm{Cs}$ distribution ratios, the products of the nitration of BOBCalixC6 are less soluble in the organic solvent. This further exacerbates the limited BOBCalixC6 solubility in the process solvent. An effort is underway to develop a more stable calixarene for the extraction of Cs. However; the scope of this flowsheet testing was to evaluate the performance of the FPEX process with the $\mathrm{BOBCalixC6}$ Cs extractant.

\section{EXPERIMENTAL}

Deionized water was used to prepare all aqueous acid solutions. The nitric acid was reagent grade from Aldrich Chemical Co. (Milwaukee, WI). Isopar ${ }^{\circledR} \mathrm{L}$ isoparaffinic diluent was obtained from Exxon Chemical Company (Houston, TX). The ${ }^{85} \mathrm{Sr}$ and ${ }^{137} \mathrm{Cs}$ radiotracers used for spiking the simulants were obtained as ${ }^{85} \mathrm{SrCl}_{2}$ in $1 \underline{\mathrm{M} \mathrm{HCl} \text { and }}{ }^{137} \mathrm{CsCl}$ in $1 \mathrm{M} \mathrm{HCl}$ from Isotope Products (Burbank, CA). The DtBuCH18C6 crown ether was purchased from Eichrom Industries, Inc. (Darien, IL). The BOBCalixC6 calixarene crown ether was received from Marshallton Research Laboratories (King, NC). The FPEX solvent used in these studies consisted of $0.075 \mathrm{M}$ DtBuCH18C6, $0.007 \quad \underline{M}$ BOBCalixC6, $0.75 \quad \underline{M}$ Cs-7SB modifier, and $0.003 \underline{\mathrm{M}}$ trioctylamine (TOA) in Isopar ${ }^{\mathbb{B}} \mathrm{L}$.

The simulant compositions used in this testing are based on a typical composition expected for leaching of spent LWR fuel with nitric acid. It was also assumed that the UREX process for the separation of uranium $(\mathrm{U})$ and technetium $(\mathrm{Tc})$ from the spent LWR would precede this process; therefore, the simulant used did not contain $\mathrm{U}$.

Analytical measurement of the radioactive tracers used in this testing $\left({ }^{241} \mathrm{Am},{ }^{154} \mathrm{Eu},{ }^{137} \mathrm{Cs}\right.$, and $\left.{ }^{85} \mathrm{Sr}\right)$ was performed using gamma spectroscopy. Concentrations of stable (nonradioactive) metals were determined by inductively coupled plasma mass spectrometry (ICP-MS). Stable metals in the organic phase were analyzed by destruction of the organic, followed by ICP-MS analysis.

\section{RESULTS AND DISCUSSION}

Flowsheet testing of the FPEX process for separating Cs and $\mathrm{Sr}$ from dissolved LWR fuel was performed using a series of $3.3-\mathrm{cm}$ diameter centrifugal contactors and simulated feed solution (see Fig. 1). The FPEX solvent used for the flowsheet testing contained BOBCalixC6 (Cs extractant), DtBuCH18C6 (Sr extractant), Cs-7SB Modifier and TOA in Isopar-L. The flowsheet shown in Fig. 2 was used for testing and was designed to meet the requirements of removing $>99.9 \% \mathrm{Cs}$ and $\mathrm{Sr} 1$ and leaving $<100 \mathrm{nCi} / \mathrm{g}$ TRU contamination in the $\mathrm{Cs} / \mathrm{Sr}$ strip product solution.

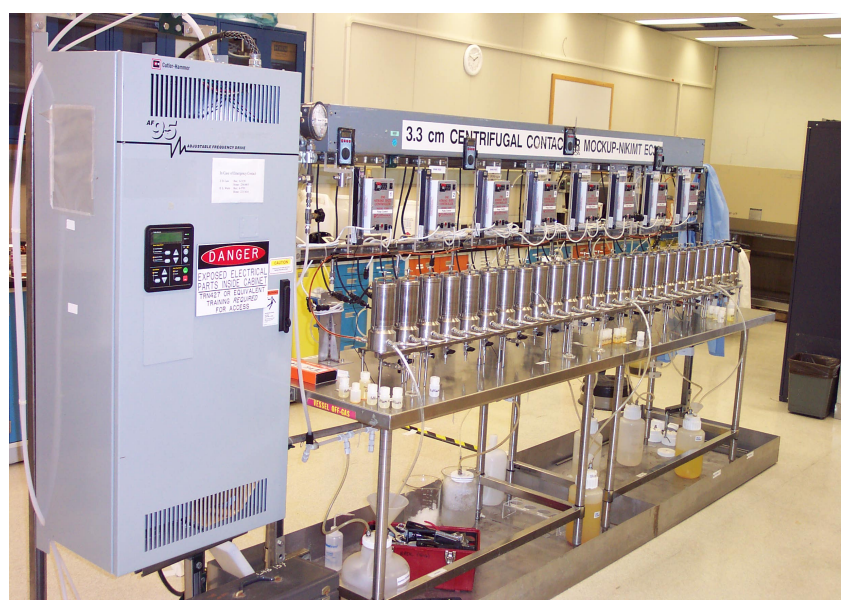

Fig. 1. This figure shows the configuration for the centrifugal contactor experiment.

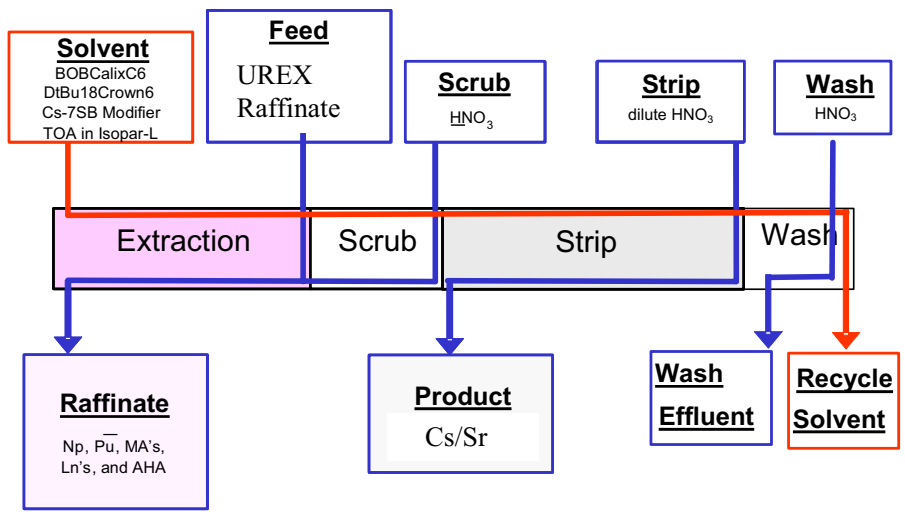

Fig. 2. This flowsheet shows the FPEX process.

The flowsheet testing consisted of approximately two hours of startup, including the initiation of feed flows and filling of contactor stages, followed by 270 minutes of operation with feed simulant. The solvent was recycled during testing for a total of 2.6 solvent turnovers within the 24 stages of contactors. Samples of each of the effluent streams were taken every 30 minutes and immediately prior to shutdown. After shutdown, liquid phases from the stages were drained into individual bottles and the two phases sampled.

The percentages of $\mathrm{Cs}, \mathrm{Sr}$, and the lanthanides in the effluent streams at the time of shutdown are shown in Table I. The removal efficiencies were $>99.99 \%$ and $>99.98 \%$ for $\mathrm{Cs}$ 
and $\mathrm{Sr}$, respectively. Greater than $99.98 \%$ of the barium $(\mathrm{Ba})$ and

Table I. Percentages of each component in effluents.

\begin{tabular}{|c|c|c|c|c|c|}
\hline $\begin{array}{c}\text { Effluent } \\
\text { Stream }\end{array}$ & Cs & Sr & Ba & La & Ce \\
\hline Raffinate & $<3 \mathrm{E}-5 \%$ & $<2 \mathrm{E}-4 \%$ & $<1 \mathrm{E}-4 \%$ & $89.7 \%$ & $90.6 \%$ \\
\hline $\begin{array}{c}\text { Strip } \\
\text { Product }\end{array}$ & $98.9 \%$ & $101 \%$ & $101 \%$ & $0.03 \%$ & $9 \mathrm{E}-4 \%$ \\
\hline $\begin{array}{c}\text { Wash } \\
\text { Effluent }\end{array}$ & $2 \mathrm{E}-04 \%$ & $<3 \mathrm{E}-4 \%$ & $<1 \mathrm{E}-4 \%$ & $3 \mathrm{E}-4 \%$ & $3 \mathrm{E}-4 \%$ \\
\hline $\begin{array}{c}\text { Effluent } \\
\text { Stream }\end{array}$ & Nd & Sm & $\mathbf{Z r}$ & $\mathbf{R b}$ & \\
\hline Raffinate & $96.6 \%$ & $96.4 \%$ & $96.1 \%$ & $<2 \mathrm{E}-04 \%$ & \\
\hline $\begin{array}{c}\text { Strip } \\
\text { Product }\end{array}$ & $1 \mathrm{E}-03 \%$ & $2 \mathrm{E}-3 \%$ & $<1 \mathrm{E}-3 \%$ & $101 \%$ & \\
\hline $\begin{array}{c}\text { Wash } \\
\text { Effluent }\end{array}$ & $2 \mathrm{E}-4 \%$ & $2 \mathrm{E}-4 \%$ & $2 \mathrm{E}-3 \%$ & $<2 \mathrm{E}-4 \%$ & \\
\hline
\end{tabular}

99.99\% of the rubidium $(\mathrm{Rb})$ were also extracted. Distribution coefficients for $\mathrm{Cs}, \mathrm{Sr}, \mathrm{Ba}$, and $\mathrm{Rb}$ were calculated on each stage. ${ }^{137} \mathrm{Cs}$ and ${ }^{90} \mathrm{Sr}$ were also spiked into the stage samples, reequilibrated, sampled and analyzed. Extraction distribution coefficients for $\mathrm{Sr}$ generally ranged from 5 to 10 . The variability in results is attributed to the difficulty in analyzing the organic phase samples by ICP. For the stage samples spiked with ${ }^{85} \mathrm{Sr}$, distribution coefficients ranged from 2.9 to 4.6. Stable Cs distribution coefficients were not determined due to difficulties analyzing the organic phase samples. However, ${ }^{137} \mathrm{Cs}$ results in the extraction section ranged from 6.7 to 9.3. Extraction distribution coefficients ranged from 2.9 to 4.4 for $\mathrm{Ba}$ and from 3.5 to 4.9 for Rb. Strip distribution coefficients for $\mathrm{Cs}$ and $\mathrm{Sr}$ were as expected; approximately 0.25 for $\mathrm{Cs}$ and 0.007 for $\mathrm{Sr}$.

To get an idea of how much TRU would be extracted with this flowsheet, ${ }^{241} \mathrm{Am}$ and ${ }^{154} \mathrm{Eu}$ were spiked into the stage samples, re-equilibrated, sampled and analyzed. Extraction distribution coefficients for Am ranged from $<0.009$ to $<0.04$ and for Eu ranged from $<0.001$ to $<0.004$. In all cases, activities in the organic phase were below analytical detection limits so actual distribution coefficients are not known. These low distribution coefficients indicate that the amount of TRU extracted with this flowsheet would be very small; however, testing with actual spent nuclear fuel will be required to verify that the $\mathrm{Cs} / \mathrm{Sr}$ strip product is non-TRU.

\section{CONCLUSIONS}

An FPEX flowsheet has been successfully demonstrated with spent LWR fuel simulant. Hydraulic performance of the process was excellent. Removal efficiencies of $>99.99$ and $>99.98 \%$ were obtained for $\mathrm{Cs}$ and $\mathrm{Sr}$, respectively. These results exceeded the process goals of $99.9 \%$ separation. Additionally, distribution coefficients for Am and Eu were very low indicating little of the TRU should be extracted with this flowsheet. Flowsheet testing with actual spent fuel is recommended to verify these results. Development of alternative calixarenes for the extraction of $\mathrm{Cs}$ are also recommended to increase the solubility and stability of the calixarene during long-term operation.

\section{ACKNOWLEDGMENTS}

This work was performed under the auspices and financial support of the United States Department of Energy, Office of Nuclear Energy, Science and Technology through contract DEAC07-05ID14517. The authors would also like to acknowledge Byron White for the analytical support provided.

\section{REFERENCES}

1. J. Laidler, "Chemical Separation Schemes for Partitioning and Transmutation Systems," ANL/CMT/CP-107557, Proc. ANS 2002 Annual Meeting, Hollywood, FL, June 9-13, (2002).

2. Horwitz, E.P.; Dietz, M.L.; Fisher, D.E. SREX: a new process for the extraction and recovery of strontium from acidic nuclear waste streams. Solvent Extr. Ion Exch. 1991, 9 (1), 1-25.

3. Wood, D.J.; Tranter, T.J.; Todd, T.A. Effect of the interference of alkali and earth metal ions on the extraction of $90 \mathrm{Sr}$ from acidic nuclear waste solutions by 18-crown-6 derivative. Solvent Extr. Ion Exch. 1995, 13 (5), 829-44.

4. McDowell, W.J. Crown ethers as solvent extraction reagents: where do we stand? Ep. Sci. and Technol. 1988, 23, 1251-68.

5. Dozol, J.F.; Simon, N.; Lamare, V.; Roquette, H.; Eymard, S.; Tournois, B.; DeMarc, D.; Macias, R.M. Solution for Cs removal from high-salinity acidic or alkaline liquid waste: the crown calix[4]arenes. Sep. Sci. and Technol. 1999,34 (6\&7), 877-909.

6. Bonnesen, P.V.; Delmau, L.H.; Haverlock, T.J.; Moyer, B.A. Alkaline-Side Extraction of Cesium from Savannah River Tank Waste Using a Calixarene Crown Ether Extractant; Oak Ridge National Laboratory: Oak Ridge, TN December 1998; Report ORNL/TM-13704.

7. Dozol, J.F.; Asfari, Z.; Hill, C.; Vicens, J. Bis-crown calix[4]arenas, their preparation process and their use for the selective extraction of cesium and actinides. French Patent n892 14245 B11385.3/MDT, Nov. 26, 1992.

8. Casnati, A.; Pochini, A.; Ungaro, R.; Ugozzoli, F.; Arnaud, F.; Fanni, S.; Schwing, M.J.; Egberink, R.J.M.; DeJong, F.; Rienhoudt, D.N. Synthesis, complexation and membrane transport studies of 1,3alternate calix[4]arene crown-6 conformers: a new class of cesium selective ionophores. J. Am. Chem. Soc. 1995, 117, 2767-77.

9. Sachleben, R.A.; Bonnesen, P.V.; Descazeaud, T.; Haverlock, T.J.; Urvoas, A.; Moyer, B.A. Surveying 
the extraction of cesium nitrate by 1,3-alternate calix[4]- arene crown-6 ethers in 1,2-dichloroethane. Solvent Extr. Ion Exch. 1999, 17 (6), 1445-59.

10. Bonnesen, P.V.; Haverlock, T.J.; Engle, N.L.; Sachleben, R.A.; Moyer, B.A. Development of Process Chemistry for the Removal of Cesium from Acidic Nuclear Waste by Calix[4]arene-crown-6 Ethers; ACS Symposium Series 757 (Calixarenes for Separations), American Chemical Society: Washington, D.C., 2000, 26-44.

11. Riddle, C. L., Baker, J. D., Law, J. D., McGrath, C. A., Meikrantz, D. H., Mincher, B. J., Peterman, D. R., and Todd, T. A. Fission Product Extraction (FPEX): Development of a Novel Solvent for the Simultaneous Separation of Strontium and Cesium from Acidic Solutions. Solvent Extr. Ion Exch. 2005, 23 (3), 449461. 